\title{
Why Sin?-A Test and an Exploration of the Social and Psychological Context of Resentment and Desire
}

\author{
Rein Nauta $\cdot$ Leon Derckx
}

Published online: 18 August 2007

(C) Springer Science + Business Media, LLC 2007

\begin{abstract}
This article focuses on the theory put forward by Donald Capps in his The Depleted Self (Sin in a narcissistic age. Minneapolis: Fortress Press, 1993) that there is a particular link between some forms of narcissism and the commitment of particular deadly sins. The data in the research reported in this paper robustly validate the idea that the psychological consequences of the bureaucratic consumer society, understood as a lack of individual well-being leading to a narcissistic defense, show the theological relevance of the deadly sins in understanding those conditions in society which on a global scale appear to threaten the individuality of the single person. Narcissism, both in its covert and overt mode, seems to be the most important variable in explaining the two factors of sin: resentment and desire. In addition to the effects already accounted for by well-being and narcissism, the possible contribution of religion and biography is explored.
\end{abstract}

Keywords Alienation $\cdot$ Narcissism $\cdot \operatorname{Sin} \cdot$ Resentment $\cdot$ Desire

\section{Introduction}

The debilitating characteristics of the modern consumer society were made the more visible in the aftermath of the financial boom on Wall Street during the years of the millennium change. While whiz kids and wise guys earned huge amounts of money by speculation and embezzlement, the ordinary people who were seduced by captains of industry to put their money in valueless stock, lost their pensions and any hope of a better future because, in order to redeem the losses caused by their superiors, many were laid off to restore the shareholders' value of the conglomerates to which they contributed their labor's worth. Perhaps more than ever before the societal conditions underscored the vulnerability of our personal existence and revealed the lack of respect for our individual welfare. Against the idea that individuals should be in charge of their own lives, recognizing the interests of

R. Nauta $(\bowtie) \cdot$ L. Derckx

Department of Religious Studies and Theology, Tilburg University,

P.O. Box 9130, 5000 HC Tilburg, The Netherlands

e-mail: R.Nauta@uvt.nl 
those with whom they are living together, the frightening discovery was made that the individual's worth was of no account, and what the individual considered to be important did not matter at all. Large conglomerates, like Enron, Ahold, WorldCom, purportedly to serve the common good of the public at large, appeared to be governed by the private selfinterest of those who were responsible for their management. Misguided by apparently expert advice, driven by a desire for conspicuous consumption as was never before possible, many lost their good sense in order to support their fragile self-esteem in a society in which only outward signs of luxury and extravagance were accepted as sure indicators of an inner state of happiness and prosperity, of psychic well being and mental stability.

However, as is argued by Donald Capps in The Depleted Self (Capps 1993), such a condition may give rise to feelings of depression, lack of meaning, and a general dissatisfaction with life. Such feelings, when their permanence is characteristic of their presence, are conducive to the expression of a more stable narcissistic predisposition. This narcissistic character orientation reveals the anxieties surrounding a fragile self-constituted by a lack of mirroring in the earliest development of the child. When the social and societal circumstances are such that they resemble the impoverished childhood situation, the defenses once learned break down and the need for repair is of the utmost importance. These modes of repair are symptomatic of their pathologies. The repair takes the form of doing more of what one had been doing, even though this was what got one into one's current state of vulnerability (Capps 1993). Narcissists' own efforts at repair are therefore counterproductive - craving for support, their demand for respect is expressive of such neediness that disappointment is unavoidable. But disappointment only increases their demands in even more obvious ways. Paranoid types of narcissists become more suspicious, although that suspicion may be unwarranted; they blame others and ascribe even more and more evil motives to them. Trying to repair their narcissistic wound they project their self-contempt onto others. They are engulfed in self-hatred and are full of contempt of the genuine love that another may feel for them. Their utter suspiciousness, in turn, drives the other away thus seeming to confirm the truth of their paranoid allegations (Capps 1993). Manipulative narcissists try to be even more successful in manipulation and deceit, in lying and fraud, so that shame may give way to grandiosity, while phallic narcissists attempt to overcome their vulnerability by relying more and more on the fantasized expectations of others' admiration and adulation. The repair takes the form of arrogance, self-glorification, aggressive competitiveness, and pseudo-masculinity, which is often demonstrated in foolish acts of bravery. Among these types perhaps a more robust divide may be made between the craving and paranoid types on the one hand, and the manipulative and phallic types on the other. The first do show resentment and jealousy as their prime emotional accord, the latter are more expressive of a feeling weakness will be never realized because the repair is merely a repetition of their human deficit of weak bravura and shallow arrogance. The way in which both try to repair their vulnerability is tragic in that sense that failure is always imminent and a permanent solution to their weakness will never be realized because the repair is merely a repetition of their human deficit.

Consequently the dominant emotion is that of shame. Shame in a most pregnant way expresses the human experience of fallibility. One feels ashamed because one is unable to live up to the internalised cultural ideal of a successful, autonomous person (Lynd 1958). Such an inner feeling of disappointment and resentment has to be masked at all costs. The appearance that everything is ok should be and can be maintained by precisely those traits and characteristics that scholars like Christopher Lasch (1979), and psychotherapists like Heinz Kohut (1966, 1971, 1977; cf. Siegel 1996) and Otto Kernberg $(1975,1989,1994)$ and others describe as narcissistic: to annul the pain of disappointed love their patients, that is, most of 
us, are facile at managing the impression they give to others, are ravenous for admiration but contemptuous of those that are manipulated in providing it, are unappeasingly hungry for emotional experiences with which to fill an inner void, and are terrified of ageing and death (cf. Ronningstam 2000, 2005). Such patients hope to find in the therapeutic relationship external support for fantasies of omnipotence and eternal youth (Kohut and Wolf 1986; Morrison 1986). On the other hand, for all his inner sufferings, the narcissist has many trait that make for success in bureaucratic institutions which put a premium on the manipulation of interpersonal relationships, discourage the formation of deep personal attachments (Sennett 1974, 1980; Stolorow 1975; Westen 1990) and at the same time provide the narcissist with the approval needed to validate a very unstable self-esteem.

In short, an individualized society sets a premium on success and excellence but at the same time, inevitably, infuses shame into everybody who fails to achieve the unrealistically high goals set in line with inflated expectations of control and success. This shame expresses itself in feelings of disappointment, meaninglessness, depression and depletion, of unhappiness in general and is conducive to the establishment of a more stable narcissistic personality syndrome which masks self-hate and low self-esteem in an excess of grandiose visibility (overt narcissism) (Rhodewalt and Morf 1995; Morf and Rhodewalt 2001; Bursten 1986; Raskin and Hall 1979, 1981) or a resentful lack of empathy and an abundance of self-pity (covert narcissism) (Ettema and Zondag 2002; Zondag 2003; Wink 1991; Miller 1992).

The tragedy of narcissism is the more evident when its relation with sin is considered. In several publications by Donald Capps $(1987,1989,1990,1992,1993)$ and Capps and Cole $(2000,2006)$ it is argued that there is a rather strong connection between this narcissistic condition and the prominence of particular deadly sins, which can be considered as narcissism-prone, namely envy and pride. Capps (1993; cf. Hiltner 1989; Sugerman 1976) suggested that the deadly sins function as an early warning system against a life lost in disharmony, hopelessness and inner conflict. The deadly sins are the subtle expression of the narcissistic woundedness of even superficially well-adjusted, God-fearing citizens, regularly attending church. Researching the relevance of sin in modern society, he asked a group of ordinary parishioners which of the eight deadly sins, presented as different attitudes about life, they considered to be the worst and which of those attitudes they most closely identified with ("this, unfortunately, describes me all too well", "this is the attitude that I have most strongly struggled to overcome"). The worst sins were considered to be melancholy (hopelessness) and lust, the most personal sins however were pride and envy (Capps 1993). This result was many times reproduced with different classes of theology students at Tilburg University, The Netherlands (cf. Nauta 2002). Capps interpreted the results as indicative of a lack of support and recognition, as a loss of affirmation and mirroring, as suggesting a kind of craving, covert, narcissism. Those who considered pride to be their worst personal sin were looking for recognition they did not receive. Those who identified with envy as their most personal sin were jealous of others less deserving, who got the praise and adulation they needed themselves. Although they considered their "mirror-hunger" inappropriate, at the same time they acclaimed their right for recognition. The central role of pride and envy is, however, dramatic evidence that those who participated in the research, ordinary church members, are mirror hungry people who thirst for self-objects whose confirming and admiring responses will nourish their famished self (Capps 1993). Acknowledging their sinfulness may also act as a reflective defense against the threat of melancholia, the individual's utter devastation when losing any hope for a better life. The sins with which both men and women struggle are not the sins that they, on objective grounds, consider the worst or most deadly. The central role of pride and envy is, 
however, dramatic evidence that those who participated in the research, ordinary church members, are mirror hungry people who thirst for self-objects whose confirming and admiring responses will nourish their famished self (Capps 1993). Furthermore, they believe that they should learn to cope with and possibly overcome their hunger for admiration and their envy of others who receive such adulation. They do not feel good about their emotional neediness, and are a little ashamed that they have these needs and seem unable to satisfy these hungers in a permanent or lasting way. In particular the covert type of narcissism is reflected in the favorite deadly sins of these ordinary people. More than just an expression of what is forbidden and should not be done, their sins reveal the vulnerability of living in a culture that threatens human existence. Real sins are disorienting, fake solutions in a situation in which the person has too few capacities and capabilities to keep going in the face of a menacing, overwhelmingly powerful reality. Sins are in fact the tragic, doomed-to-fail attempts to maintain one's self-esteem in a life that expresses the need for redemption in its sinfulness. Our research, the results of which we are about to present, aimed to find a more empirical base for the relation between sin and narcissism, so eloquently argued by Donald Capps.

The research on deadly sins, which Capps used to illustrate his argument for the depleted self, asked the respondents first to indicate which of the deadly sins, represented as attitudes, they considered the worst (i.e., the most destructive or damaging). Next they were asked to circle the one attitude with which they, personally, most closely identified ("The attitude about which you would say: This unfortunately, describes me all to well,' or 'This is the attitude that I have especially struggled to overcome'). In representing the eight deadly sins a single description for each was used. After consulting with seminary students and a group of laity in a congregation in Philadelphia a definite list of eight descriptions resulted. However, the relation with narcissism remained in those research projects more or less a matter of conviction by argument. It is the purpose of this paper to report an extension of that research, incorporating measures of psychological well-being and narcissism and to use more behaviorally oriented measures of the deadly sins.

\section{Model and research procedure}

The simple model used in the original research on the relation of narcissism and deadly sins hypothesizes a direct link between narcissism, in particular the craving and paranoid modes, and the deadly sins of envy, pride, and melancholy (Capps and Cole 2000). This kind of narcissism may be considered a psychological reaction to the debilitating effects of a bureaucratic consumer society in which individuals are made vulnerable in all sorts of ways and are not recognized for their inherent worth as fellow human beings. The crucial hypothesis to be tested is not that several measures of psychological discomfort (unhappiness, dissatisfaction with life, loss of meaning, depressive mood) are the immediate determinants of committing an act of sin, but that the sinful behavior of modern men and women is best explained by their narcissistic orientation towards life. This narcissism however is a result of an effort to cope with the harmful effects on individual well-being of a society in which the significance and sanctity of the individual have been lost.

In a sample of 501 respondents working in some kind of pastoral, therapeutic or theological capacity, the hypotheses regarding the relations between the concepts explicated in the theoretical model were tested. In this sample 329 men and 172 women were included. Two hundred and fifty-one respondents were Catholic, 192 were Protestant. The modal age category (180 respondents) was the one between 51-60 years. 


\section{Research instruments}

Several instruments were used, adapted, or developed to measure the various concepts used in the empirical test of the hypothesis.

Psychological well-being

Several measures were used to operationalize the concept of psychological well-being. The first one is the Meaning in Life scale developed by Debats (1996). Typical items are: 'I have a clear idea what I want to do with my life'; 'There is nothing in my life in which I really believe.' The total scale of 28 items encompasses two subscales: Perspective- the degree to which people are able to formulate life goals from a higher order perspective; and Realization - the degree to which such goals are in fact realized. In our research a shortened form of 12 items was used (Zondag 2001) resulting in an eight item Perspective subscale (alpha 0.82) and a four item Realization subscale (alpha 0.76). A second measure used, to operationalize the concept of psychological well-being, is the Satisfaction with Life Scale (Diener et al. 1985). This scale consists of five items selected from a wider domain of 48. Representative items include: 'In most ways my life is close to my ideal'. The onedimensional scale used in our research shows a satisfactory reliability (alpha 0.79). A third measure, used to operationalize the concept of psychological well-being, was a Dutch variant of a composite of two subscales of the Depression Adjective Check List (Lubin 1965, 1981; Arrindell and van Rooijen 1999) measuring dysphoria (22 items) and euphoria (12 items). The respondent is asked to cross out those affects that give expression to his momentary emotional feelings. The resulting sum score indicates the degree to which a person experiences negative feelings or moods, or lacks positive feelings or moods.

\section{Narcissism}

The instrument developed by Ettema and Zondag (2002) to measure non-pathological aspects of narcissism was used. This scale, the Netherlands Narcissism Scale (NNS), measures the degree to which people think that their self-esteem is dependent on the opinion of others. The fear to fail in the eyes of the observer and therefore to lose a positive evaluation is a stimulus to manifest a behavior that is in accord with the supposed norms of anonymous critics. Correct self-presentation is consequently considered to be a form of mental self-help. The scale measures two dimensions of narcissism: overt (Raskin and Hall 1979, 1981) and covert narcissism (Hendin and Cheek 1997). The subscale for overt narcissism has a reliability of alpha .68; the subscale measuring covert narcissism has a reliability of .84 . Representative items are: 'I am a person with the capability to lead' (overt), 'I find it easy to bring others to do what I like them to' (overt). The overt narcissist is a person who is arrogant, manipulative, complacent, who needs others for admiration and adulation. Items representing covert narcissism are: 'When I am recognized by others I feel really alive,' and 'Often I take other people's loose remarks very personally.'

Deadly sins

In formulating the items for the Deadly Sins Scale earlier work by Backus (1969) and Capps (1987) was reinterpreted. The language used by Backus was considered too archaic and of little relevance in an age of increasing secularization and diminishing faith. For example an item such as: 'Even during sexual embrace, I would still place God first rather 
than set Him and His will aside,' borders on the ridiculous if presented to a postmodern public. The descriptions used by Capps in his research on deadly sins were however the starting point from which to phrase several items exemplary of a particular sin. An operationalization of the deadly sin of Lust used as indicators: manipulation, desire, lust object, self-interest (Derckx 2003). Items measuring this sin were then formulated for example as: 'I am sometimes nice to my partner so that I can make love,' and 'Sometimes I fantasize over sleeping around,' or 'I can hardly keep my eyes off beautiful men and women,' and 'I would not like to give up my sexual fantasies and pleasures,' 'I cannot resist flirting with the men/women I meet,' 'I am often absorbed in erotic daydreams.' More than in other research on sin a behavioral reference was taken into account when formulating these items. After try-outs with students and staff of the Tilburg Theological Faculty, a definite instrument was developed including four items for each deadly $\sin ^{1}$ Although most

${ }^{1}$ The definite Deadly Sins Scale contains the following items:

1. I like to be the center of attention.

Pride

2. I attach great importance to a well-paid job.

Greed

3. Sometimes I fantasize over sleeping around.

Lust

4. I am often angry without knowing why.

Anger

5. Most of the time I am the first to finish my meal.

Gluttony

6. Successful people should encounter more difficulties in their lives.

Envy

7. I feel not responsible for all the world's sorrow.

Apathy

8. I have been disappointed in many of the things I have done.

9. I have a sharper insight into social situations than most people.

Melancholy

10. There is nothing I like better than buying all sorts of things.

Pride

11. I cannot help flirting with the women/men I meet.

Greed

12. When I am annoyed, I easily lose my temper.

Lust

13. Once I have started to indulge myself in eating sweets, I find it very difficult to stop.

Anger

14. I find it difficult to empathize spontaneously with the good fortune of others.

Gluttony

15. There are only very few issues to which I can commit myself wholeheartedly.

Envy

Apathy

16. I no longer believe in the good intentions of man.

17. Sometimes people look up to me.

Melancholy

Pride

18. I look always for opportunities to better my financial position.

Greed

19. I find it very difficult to keep my eyes off beautiful people.

Lust

20. Sometimes anger makes my head spin.

Anger

21. I very often eat more than what is good for me.

Gluttony

22. Most of the time people in high positions are lucky as well.

Envy

Apathy

23. I do not care for the problems of other people.

Melancholy

24. Life has not been good to me; I expected a better deal.

Pride

25. I have gone far in the world.

Greed

26. I really consider it an exaggeration to tip for any small service.

Lust

27. I am often absorbed in erotic daydreams.

Anger

28. When I am angry, people who are close to me must suffer.

Gluttony

29. With respect to eating and drinking I find it very hard to restrain myself.

Envy

30. I really wonder if successful people are happy.

Apathy

31. At work I encounter many bores.

Melancholy

32. Sometimes I feel that my life has failed.

Scale values:

$1=$ Do not agree at all, $2=$ do not agree, $3=$ do not agree a little, $4=$ do not agree, neither disagree, $5=$ agree a little, $6=$ agree, $7=$ do totally agree 
of the subscales measuring one of the eight deadly sins reached acceptable levels of reliability in measurement (only apathy had an alpha $<.50$ ), the intercorrelation between the subscales was substantial. After factor analysis (varimax rotation) a ten factor solution explained $57.5 \%$ of the total variance. Of these ten factors with eigenvalues larger than 1 , eight were interpretable each one of which could be identified with one of the eight deadly sins. Using the screen tests a two-factor solution demonstrated however a more robust solution, explaining $22.6 \%$ of the total variance. On the first factor (alpha 0.74) loaded items measuring melancholia, anger, and envy. On the second factor (alpha 0.74) loaded items measuring lust, greed, and pride. Neither apathy nor gluttony reached the criteria for inclusion in either one or the other of the two factors (loading more than 0.30 on one of the factors but not on both). The first dimension seemed to measure Resentment, while the second dimension seemed to measure Desire. The instrument was introduced to the respondents as a questionnaire about life orientations.

In Table 1 the intercorrelations of the variables of central interest to our research related to well-being, narcissism, and sin are presented. Noteworthy is the highly positive and significant correlation between Resentment and covert narcissism (0.63). This is not surprising as both variables are different conceptualizations of a negative mood or a pessimistic perspective on life either on a behavioral, cognitive or emotional level. The absence of such correlations might cause more wonder then their presence. Also there are high intercorrelations between the well-being variables themselves.

\section{Results}

The hierarchical regression analysis, to be used to test the hypothesized relations will give some insight into the effects of the different clusters in explaining the predominance of sin

Table 1 Correlations between sin, well-being, and narcissism

\begin{tabular}{|c|c|c|c|c|c|c|c|c|}
\hline & Resentment & t Desire & $\begin{array}{l}\text { Covert } \\
\text { narcissism }\end{array}$ & $\begin{array}{l}\text { Overt } \\
\text { narcissism }\end{array}$ & $\begin{array}{l}\text { Meaning } \\
\text { in life: } \\
\text { perspective }\end{array}$ & $\begin{array}{l}\text { Meaning } \\
\text { in life: } \\
\text { e fulfillment }\end{array}$ & $\begin{array}{l}\text { Satisfaction } \\
\text { with life }\end{array}$ & $\begin{array}{l}\text { Depressive } \\
\text { affect }\end{array}$ \\
\hline Desire & $0.299 *$ & & & & & & & \\
\hline $\begin{array}{l}\text { Covert } \\
\text { narcissism }\end{array}$ & $0.631 * *$ & $0.322 * *$ & & & & & & \\
\hline $\begin{array}{l}\text { Overt } \\
\text { narcissism }\end{array}$ & $-0.145^{*}$ & $0.164 * *$ & 0.018 & & & & & \\
\hline $\begin{array}{l}\text { Meaning } \\
\text { in life: } \\
\text { perspective }\end{array}$ & $0.321 * *$ & -0.101 & $-0.264^{*}$ & $0.366^{* *}$ & & & & \\
\hline $\begin{array}{l}\text { Meaning } \\
\text { in life: } \\
\text { Fulfillment }\end{array}$ & $-0.538^{*}$ & $-0.167^{*}$ & -0.516 & $0.325 * *$ & $0.637 * *$ & & & \\
\hline $\begin{array}{l}\text { Satisfaction } \\
\text { with life }\end{array}$ & $-0.412 *$ & -0.042 & $-0.387^{*}$ & $0.310^{*}$ & $0.593 * *$ & $0.709 *$ & & \\
\hline $\begin{array}{l}\text { Depressive } \\
\text { affect }\end{array}$ & $0.457 * *$ & 0.062 & $0.444 * *$ & $-0.311^{*}$ & $-0.443^{*}$ & $-0.619 *$ & $-0.598^{*}$ & \\
\hline
\end{tabular}

${ }^{*} p<0.05$

$* * p<0.01$ 
among those who suffer from narcissistic woundedness, unhappiness, and a feeling of alienation and a lack of meaning in life. If significant changes in $R$ square can be attributed to the addition of such clusters entered as separate blocks to the regression equation, individual variables constituting those clusters may also be deemed, if significant, of relevance in explaining the criterion (Cohen and Cohen 1975; Nauta 1982).

Table 2 shows, as expected, that narcissism however is more important than (a lack of personal) well-being in explaining variance in the two factors structuring the deadly sins. The test of the model requires that the addition of the narcissism cluster leads to a significant and larger amount of variance explained in either Resentment or Desire than is already explained by the cluster of well-being variables. On the other hand the addition of well-being variables to an equation already containing the narcissism cluster should either be not significant or explain a smaller amount of variance than is explained by the narcissism variables. Table 2 shows that this is the case, both conditions prevail. The narcissism cluster explains a larger portion of the variance in each of the two sin factors when entered first in the regression equation: Resentment $-R$ square narcissism $=0.426$ vs. $R$ square well-being $=0.317$; Desire $-R$ square narcissism $=0.151$ vs. $R$ square well-being $=$ 0.035 . Also narcissism, when entered after the well-being variables are taken into the equation, explains a larger portion of the variance than the well-being variables do: Resentment $-R$ square change narcissism $=0.155$ vs. $R$ square change well-being $=0.046$; Desire $-R$ square change narcissism $=0.142$ vs. $R$ square change well-being $=0.026$.

It appears to be the case that Resentment is most dependent on covert narcissism (beta= $0.483, p<0.001$ ) and on a lack of fulfillment in the life goals once chosen (beta $=-0.232, p<$ 0.001 ). The sins of Desire on the other hand are related to both overt narcissism (beta $=0.241$, $p<0.001$ ) and covert narcissism (beta $=0.307, p<0.001$ ) and also on satisfaction with life (beta $=0.164, p<0.001$ ).

Resentment is best explained by covert narcissism (beta $=0.483, p<0.001)$ and by a lack of fulfillment in the life goals once chosen (beta $=-0.232, p<0.001$ ). Those who feel that they have drawn a losing number in the lottery of life try to excuse and repair their situation by committing the sins of envy, anger, and melancholia. They are jealous of those who seem to win the rat race of corporate power games, full of resentment about a life failed, and angry that others succeed where they themselves cannot find the way ahead. Their sinfulness may also be understood as a form of alienation dominated by an experience of powerlessness.

Desire, on the other hand, is not only an expression of overt narcissism (beta $=0.241, p<$ 0.001 ), as expected, but also determined, and even more so, by covert narcissism (beta= $0.307, p<0.001)$. The double determination by both aspects of narcissism illuminates the deep and tragic grounds of an outwardly successful defense against the societal attacks on a

Table 2 Hierarchical regression of resentment and desire on well-being and narcissism

\begin{tabular}{llllll}
\hline & Resentment & & & Desire & \\
\cline { 2 - 3 } \cline { 5 - 6 } & $R$ square & $R$ square change & & $R$ square & $R$ square change \\
\hline Well-being & $0.317^{* * *}$ & & & $0.035^{* * *}$ & \\
Well-being \& narcissism & $0.472^{* * *}$ & $0.155^{* * *}$ & & $0.177^{* * *}$ & $0.142^{* * *}$ \\
Narcissism & $0.426^{* * *}$ & & & $0.151^{* * *}$ & \\
Narcissism \& well-being & $0.472^{* * *}$ & $0.046^{* * *}$ & & $0.177^{* * *}$ & $0.026^{* *}$ \\
\hline
\end{tabular}

$* * * p<0.001$

$* * p<0.01$

Springer 
fragile self. Although committing the sins of desire appears to be related, be it as effect or cause, to a happy life (satisfaction in life makes a positive contribution in explaining the variance in Desire: beta $=0.164, p<0.01)$, the slightly negative effect of the meaning variable: Perspective (beta $=-0.123, p<0.05$ ), does show that a lack of perspective may contribute to the superficial gaiety of those who lose their lives in satisfying their desires. The sinfulness of desire can perhaps best be understood as a form of alienation dominated by an experience of meaninglessness.

\section{Biography and religion}

Apart from the effects of narcissism, of powerlessness, and meaninglessness, sinful behavior should also be determined by differences in individual biography, while it might be theologically self-evident that the commitment of sins varies according to substance and depth of religious convictions. Both these common sense hypotheses were explored. To explore the relation between sin, biography, and religion some instruments providing measurements of sex, age, marital status, and income were included as well as measures of religious upbringing, church membership, doctrinal agreement, religious participation, and the importance attached to religion.

Biographical variables explain about $3 \%$ of the variance in Resentment $(R$ square $=$ $0.034, p<0.001)$ and about $10 \%$ of the variance in Desire $(R$ square $=0.101, p<0.001)$ when entered as a block first into a regression equation to which well-being and narcissism will be added. When the biographical variables as a block are entered last into the regression equation, after well-being and narcissism are already included, the change in the amount of explained variance is just $2 \%$ in Resentment ( $R$ square change biography $=0.024, p<0.001$ ), while the increase in explained variance in Desire is $10 \%$ ( $R$ square change biography= $0.105, p<0.001)$. Of the biographical variables included, age appears to be most relevant in explaining sin. The older people are, the more they fall prey to the sins of Resentment: melancholy, anger, envy (beta age $=0.119, p<0.01$ ), the less however they indulge in the sins of Desire (beta age $=-0.131, p<0.01$ ). Desire appears to be the sin of younger, wealthier (beta income $=0.183, p<0.001$ ) men (beta gender $=0.217, p<0.001$ ). Lust, greed and pride-indiscriminate sex, the accumulation of meaningless possessions, and an arrogant exhibitionism - act as the grandiose defense against a tragic sense of depletion and a fragile notion of self-worth.

Although many agnostic politicians and intellectuals in the Netherlands are still convinced of the gain for public morality to be found in a return to some kind of enlightened religion, our analysis appears to suggest that religion does not matter in matters of morality. The direct effects of the religious variables taken as a first block into the regression equation explaining the variance in Resentment respectively Desire are very small and non-significant. If there is any religious effect to be found at all (there is just some significant increase in $R$ square: $.016, p<0.05$, when religious variables as a block are entered in the regression equation predicting Rancour after well-being and narcissism are already part of that equation), then it seems to be the case that religion rather supports instead of detracts from sin. While covert narcissism and a lack of fulfillment in reaching one's life goals are still the main predictors of Resentment, in particular agreement with church doctrine contributes positively to the commitment of the sins of Resentment: melancholy, anger and envy (beta $=0.100, p<0.01$ ). The middle-aged, well-to-do, law abiding, churchgoing citizens who make their living of the divine working in some kind of caring profession who participated in our research score higher on Resentment the more 
they agree with the doctrine of the church-which says: you shall not sin. However it may also be the case that those who know the law are the most conscious of trespassing against it. If the latter is the case the relation between Resentment and religion may be more reflective, rather than pragmatic. Instead of being guilty of hypocrisy the respondents in our research may illustrate the tragic condition of men as described in the letter of the apostle Paul to the Romans (Romans 7:19): 'For the good that I would I do not: but the evil which I would not, that I do.'

The data then may support the theological doctrine of the fallenness of men, but they also suggest that religion is in fact not more than an epiphenomenon of life instead of its sole and primary base.

\section{Conclusion}

All in all, it seems that the model developed by Donald Capps in his The Depleted Self (Capps 1993) about the psychological consequences of the bureaucratic consumer society and the theological relevance of the deadly sins in understanding those conditions in society which on a global scale appear to threaten the individuality of the single person, are robustly supported by the data in this research. Not only is this research, conducted in the Netherlands, robust in the sense that the different concepts distinguished in the model are empirically validated, but also robust in the sense that the expected relations between sin and narcissism are reproduced, as in the American studies, using different methods, and appear to be more differentiated than expected. Also the exploration of the effects of biography and religion did show the dominant importance of narcissism in explaining the variance in sin. Age and gender contributed in a very minor way to the explanation of both Resentment and Desire, while the effect of religion on sin was practically nihil. Narcissism seems to be the most important variable in explaining deadly sins. The additional, but less important explanatory contribution of a lack of meaning, either as a loss of perspective or as a failure in realization of goals once chosen, illustrates the alienated condition of those who loose themselves in sin. While the connection between $\sin$ and alienation may be theologically just a tautology, the psychological impact of narcissism refers to the tragic reality of modern life.

\section{References}

Arrindell, W. A., \& van Rooijen, L. B. (1999). De VROPSOM: De meting van depressief affect met de Nederlandse bewerking van de Depression Adjective Check Lists (DACL). Gedragstherapie, 32, 297-304.

Backus, D. W. (1969). The seven deadly sins: Their meaning and measurement. Minneapolis, MN: University of Minnesota.

Bursten, B. (1986). Some narcissistic personality types. In A. P. Morrison (Ed.), Essential papers on narcissism (pp. 377-402). New York: New York University Press.

Capps, D. (1987). Deadly sins and saving virtues. Philadelphia: Fortress Press.

Capps, D. (1989). The deadly sins and saving virtues: How they are viewed by laity. Pastoral Psychology, 37, 229-253.

Capps, D. (1990). Sin, narcissism, and the changing face of conversion. Journal of Religion and Health, 29, $233-251$

Capps, D. (1992). The deadly sins and saving virtues: How they are viewed by clergy. Pastoral Psychology, 40, 209-233.

Capps, D. (1993). The depleted self. Sin in a narcissistic age. Minneapolis: Fortress Press. 
Capps, D., \& Cole, A. H. (2000). The deadly sins and saving virtues: How they are viewed today by laity. Pastoral Psychology, 48, 359-376.

Capps, D., \& Cole, A. H. (2006). The deadly sins and saving virtues: How they are viewed today by clergy. Pastoral Psychology, 54, 517-534.

Cohen, J., \& Cohen, P. (1975). Applied multiple regression correlation analysis for the behavioural sciences. Hillsdale, NJ: Erlbaum.

Debats, D. L. (1996). Meaning in life. Psychometric, clinical and phenomenological aspects. Enschede, The Netherlands: FEBO.

Derckx, L. (2003). Tragic life. The deadly sin as an indicator of actual discontent. In H. H. M. Roebben \& L. van der Tuin (Eds.), Practical theology and the interpretation of crossing boundaries. Essays in honour of Professor M.P.J. van Knippenberg (pp. 19-37). Münster, Germany: LIT Verlag.

Diener, E., Emmons, R. A., Larsen, R. J., \& Griffin, S. (1985). The satisfaction with life scale. Journal of Personality Assessment, 49, 71-75.

Ettema, H., \& Zondag, H. (2002). De Nederlandse Narcisme Schaal (NNS). De Psycholoog, 5, 250-256.

Hendin, H. M., \& Cheek, J. M. (1997). Assessing hypersensitive narcissism: a re-examination of Murray's narcissism scale. Journal of Research in Personality, 31, 588-599.

Hiltner, S. (1989). Sin: Theological and psychological perspectives. In L. Aden \& D. G. Benner (Eds.), Counseling and the human predicament. A study of sin, guilt and forgiveness (pp. 23-36). Grand Rapids, MI: Baker Book House.

Kernberg, O. F. (1975). Borderline conditions and pathological narcissism. New York: Jason Aronson.

Kernberg, O. F. (1989). Narcissistic personality disorder. Philadelphia: Saunders.

Kernberg, O. F. (1994). Internal world and external reality: Object relations theory applied. Northvale, NJ: Aronson.

Kohut, H. (1966). Forms and transformations of narcissism. Journal of the American Psychoanalytic Association, 14, 243-272.

Kohut, H. (1971). The analysis of the self. New York: International Universities Press.

Kohut, H. (1977). The restoration of the self. New York: International Universities Press.

Kohut, H., \& Wolf, E. S. (1986). The disorders of the self and their treatment. In A. P. Morrison (Ed.), Essential papers on narcissism (pp. 175-196). New York: New York University Press.

Lasch, C. (1979). The culture of narcissism: American life in an age of diminishing expectations. New York: Warner Books.

Lubin, B. (1965). Adjective checklists for measurement of depression. Archives of General Psychiatry, 12, $57-62$.

Lubin, B. (1981). Manual for the depression adjective check lists. San Diego, CA: Educational and Industrial Testing Service.

Lynd, H. M. (1958). On shame and the search for identity. New York: Science Editions.

Miller, A. (1992). Depression and grandiosity as related forms of narcissistic disturbances. In D. Capps \& R. K. Fenn (Eds.), Individualism reconsidered. Readings bearing on the endangered self in modern society (pp. 359-371). Princeton, NJ: Center for Religion, Self and Society, Princeton Theological Seminary.

Morf, C., \& Rhodewalt, F. (2001). Unraveling the paradoxes of narcissism. A dynamic self-regulatory processing model. Psychological Inquiry, 12, 177-196.

Morrison, A. P. (Ed.). (1986). Essential papers on narcissism. New York: New York, University Press.

Nauta, R. (1982). Motivatie en gedrag. Verschil en samenhang tussen studie, politiek en cultuur. Assen, The Netherlands: Van Gorcum.

Nauta, R. (2002). Echte en erge zonden: een inleiding. In R. Nauta (Ed.), Over zonde en zonden. Opstellen over de tragiek van het bestaan (pp. 7-15). Nijmegen, The Netherlands: Valkhof Pers.

Raskin, R. N., \& Hall, C. S. (1979). A narcissistic personality inventory. Psychological Reports, 45, 590.

Raskin, R. N., \& Hall, C. S. (1981). Narcissistic personality inventory: Alternate from reliability and further evidence of construction validity. Journal of Personality Assessment, 45, 159-162.

Rhodewalt, F., \& Morf, C. (1995). Self and interpersonal correlates of the narcissistic personality inventory: A review and new findings. Journal of Research in Personality, 29, 1-23.

Ronningstam, E. F. (Ed.). (2000). Disorders of narcissism: Diagnostic, clinical and empirical implications. North Vale, NJ: Aronson.

Ronningstam, E. F. (2005). Identifying and understanding the narcissistic personality. New York: Oxford University Press.

Sennet, R. (1974). The fall of public man. Cambridge: Cambridge University Press.

Sennett, R. (1980). Authority. New York: Alfred A. Knopf.

Siegel, A.M. (1996). Heinz Kohut and the psychology of the self. London: Routledge.

Stolorow, R. D. (1975). Toward a functional definition of narcissism. International Journal of Psychoanalysis, 56, 179-185. 
Sugerman, S. (1976). Sin and madness: Studies in narcissism. Philadelphia: Westminster Press.

Westen, D. (1990). The relations among narcissism, egocentrism, self-concept and self-esteem. Experimental, clinical and theoretical considerations. Psychoanalysis and Contemporary Thought, 13, 183-239.

Wink, P. (1991). Two faces of narcissism. Journal of Personality and Social Psychology, 61, 590-597.

Zondag, H. J. (2001). Involved, loyal, alienated, and detached. The commitment of pastors. Pastoral Psychology, 49, 311-323.

Zondag, H. (2003). Evenwichtig, kwetsbaar, openlijk en maskerend. Narcistische stijlen van Nederlandse pastores. Praktische Theologie, 30, 328-344. 